\title{
The impacts of governance on Environmental Pollution in some countries of Middle East and sub- Saharan Africa: The Evidence from panel Quantile Regression and Causality
}

Melike Bildirici ( $\square$ melikebildirici@gmail.com )

Yildiz Teknik Universitesi https://orcid.org/0000-0003-3925-844X

\section{Research Article}

Keywords: Governance, panel quantile regression panel causality test, environmental pollution

Posted Date: March 15th, 2021

DOl: https://doi.org/10.21203/rs.3.rs-190567/v1

License: (9) This work is licensed under a Creative Commons Attribution 4.0 International License. Read Full License

Version of Record: A version of this preprint was published at Environmental Science and Pollution Research on October 19th, 2021. See the published version at https://doi.org/10.1007/s11356-02115716-2. 
The impacts of governance on Environmental Pollution in some countries of Middle East and subSaharan Africa : The Evidence from panel Quantile Regression and Causality

\author{
Melike Bildirici \\ Prof. Dr. Yildiz Tech.Uni., FEAS,Dept.of Economics, Esenlerr/ISTANBUL \\ e-mail:melikebildirici@gmail.com
}

\begin{abstract}
In some countries of the Middle East and sub-Saharan Africa, it was studied the impacts of governance and FDI on environmental pollution over the period of 1996-2018 by the Panel Quantile and Granger causality methods. The countries were selected by considering two different measurements, EPI (2020) and governance index (2020). Accordingly EPI(2020), these countries have low scores in terms of environmental quality and in governance index(2020), they have bad governance scores because of inefficient regulatory structures, government bureaucracy, weak law enforcement, etc. Panel Quantile regression revealed the evidence of the long-run relation among the environmental pollution, the governance and FDI. Accordingly Quantile regression results, governance has the greatest positive effect on $\mathrm{CO}_{2}$ emission. Both traditional and Dumitrescu-Hurlin $(\mathrm{DH})$ causality methods found the evidence of causality among governance and environmental pollution in the context of two parameters of governance, as the evidences of unidirectional causal nexus from political governance and FDI to environmental pollution and from economic governance, and FDI to environmental pollution.
\end{abstract}

Key Words: Governance, panel quantile regression panel causality test, environmental pollution,

\title{
1. Introduction
}

Environmental pollution under the influence of dangerous pollutants such as $\mathrm{CO}_{2}, \mathrm{NO}_{\mathrm{x}}$, and GHG became a major threat across the worldwide. According to IEA(2019), $\mathrm{CO}_{2}$ emissions through the world rose 33.1 billion tons in 2018, which is about $145 \%$ above pre-industrial levels. (Dean, et al., 2018). The reasons for the rise in $\mathrm{CO}_{2}$ releases have been discussed in many papers accented the impacts of various factors. Although in pursuit of Grossman and Krueger(1991) ${ }^{1}$., the impacts of industrialization on environmental pollution were analyzed by many papers, a few papers accented the importance of governance. Governance has impact both on economic growth and environmental pollution. A few environmental economist discussed that governance has an important role on environmental pollution (Danish et al. 2019). In the context of environmental damages, the government system and institution quality affect environmental quality both directly and indirectly. Good governance helps to decrease the level of pollution(e.g. Leonard, 1988; Shandra et al., 2008; Clapp and Dauvergne, 2005; Jorgenson, 2009) and it contributes to the environmental improvement (Hassan et al. 2020) and regulation of emission level.

Nowadays, institutional quality and strong institution structure are needed as the basic tools (Liu et al.;2020) to decrease pollution levels (Hosseini and Kaneko: 2013) through property rights, the effective judicial system, etc.. And the faults in governance support corruption in the environmental arena

\footnotetext{
${ }^{1}$ They showed that the economic development tends to accelerate environmental pollution problems once a certain GDP per capita level is reached
} 
(Leitao: 2016). So, escapes in rules would do it difficult for the realized of the rule that decreases CO2 releases (Abid: 2016; Liu et al:2020). Moreover, institutional quality in the frame of governance can control the impacts of $\mathrm{CO} 2$ releases increasing on the shadow economy and corruption (Goelet al.: 2013).

FDI as another factor of environmental pollution can cause the important damages on environmental, and it is affected by governance. The nexus between FDI, environmental and sustainability was explored by Brundtland and WCED(1987). Some papers showed that energy consumption under the influence of FDI inflows is significant reason of environmental pollution in the frame of the PHH(Pollution Haven Hypothesis) that was developed by Copeland and Taylor (1994). Bokpin(2017) showed that a great quantity of FDI inflows to less-developed nations are ecologically inefficient and highly polluting manufacturing methods originating from developed nations. In the recent years, some papers discuss that the less-developed countries live a deepening foreigndebt, with governments incorporating exemptions into environmental regulations planned to keep thenatural environment from activities in diverse sectors of the economy (e.g. Leonard, 1988; Shandra et al., 2008, Jorgenson, 2009, Clapp and Dauvergne, 2005). Peres et al.(2018), Wang andChen (2014) and Li et al.,(2019) analysed the relation among good governance, $\mathrm{CO}_{2}$ releases and FDI. The impacts of FDI on the environmental damages of host country are based upon the level of governance. Governance of the host country affects behaviors and policies of transnational firms (Wang and Chen 2014). These firms put pressure to corrupt policies of host countries to be positively affected by environmental regulations (Cole andFredriksson 2009). Desbordes and Vauday (2007) signed that these firms provide regulatory and substantial tax advantages. If it is explained briefly, FDI inflows have adverse effect on environmental sustainability of less developed countries and the relation between environmental sustainability and FDI is depend on the role of institutions and governance.

In this paper, the long-run relation and causal link among environmental pollution, governance, FDI inflow, and real GDP for a sample of the countries consisting of Afghanistan, Angola, Bangladesh, Benin, Cameroon, Congo Dem., Congo, Chad, Central African Rep, Ethiopia, Ghana, Gambia, Eritrea, Iraq, Kenya, Lesotho, Madagascar, Mali, Mozambique, Myanmar, Niger, Pakistan, Syria, Uganda, Zimbabwe by using Quantile panel regression, and causality tests will be analysed. The countries were selected by depending on the Global Environment Index (EPI:2020) and governance performance index (2020) of the countries. These countries have low scores of environmental quality. And accordingly other index, the selected countries are categorized by inefficient regulatory structures, government bureaucracy, and weak law enforcement. Firstly, panel Quantile regression(PQR) method will be applied. PQR will give the long-run estimations to determine accurate economic policy suggestions that cover the crucial points in this paper. $\mathrm{PQR}$ is robust to heavy distributions and outliers. By employing PQR method, the determinants of $\mathrm{CO}_{2}$ releases through the conditional distribution will be found. This method will permit to estimate the conditional heterogeneous covariance impacts of $\mathrm{CO} 2$ releases. The results of PQR will be compared with one's of FMOLS and DOLS. Lastly, causality test will determine the direction of causality that is very significant to determine appropriate economic policy suggestions. If these methods give the same results, the results will be considered as correct.

The design of this article was constructed in the following way. The literature section is given in the following section. The third part presents the data and definitions of the variables. 
Methodology is explained in the section four. The fifth section supplies the econometric results.

\section{Literature}

Dryzek (1987) suggested radical decentralization on environmental degradation. Desai (1998) showed that in developing countries, corruption contributes to environmental problems. Fredriksson and Svensson (2003) showed that environmental policies are affected by corruption and political instability. And they showed that governance and the levels of corruption have an adverse impact on the stringency of environmental regulation, and that the impact can be positive at high levels. Fredrikssonet.al. (2004), Pellegrini and Gerlagh (2006), Damaniaet al(2003) found that corruption decreases the severity of environmental regulations. Bhattarai and Hammig(2004) found the support for the EKC hypothesis in the context of control variables of institutional factors and the rule of law. Fredriksson et al. (2005) found that democracy encourages the administration to better characterize public preferences and that the government can prefer a more strict environmental policy. Bernauer and Koubi(2009), Wilson and Damania(2005), Yang et al.(2018) showed green parties' strength and regulatory systems have nonnegative effect on environmental quality. In EKC framework, Welsch (2004) tested the direct and indirect impacts of corruption on environmental quality and determined that it hampers the application and formation of environmental regulations. Cole (2007) found that corruption positively affects both $\mathrm{CO}_{2}$ and sulfur $\left(\mathrm{SO}_{2}\right)$ emissions for 94 countries in the period of 1987-2000. Dutt (2009) examined the relation between the environment and income in the context of institution and governance. Gani (2012) who examined the relationship between $\mathrm{CO}_{2}$ releases and five dimensions of governance in 99 developing countries found that good governance enables lower $\mathrm{CO}_{2}$ releases. Halkos and Tzeremes(2013) found the important the relationship between $\mathrm{CO} 2$ emission and governance by non-parametric estimator. Halkos et al.(2015), for U.K, Germany and France, and tested the impact of regional quality on environment. They determined that high regional quality will not enable environmental effectiveness. Zhang et al. (2016) tested the influence of corruption on $\mathrm{CO}_{2}$ releases in APEC countries from 1992 to 2012 by Panel quantile regression model. Their findings indicated that the impact is adverse and statistically significant. Sarkodie and Adams (2018) showed that corruption control, better governess, and political institutional quality could support to mitigate pollution in South Africa. Abid (2017), in EU countries, determined that a higher institutional quality can decrease $\mathrm{CO}_{2}$ releases, and that institutional quality is not significant in the MEA countries. Danish et al(2019), for BRICS countries, tested the importance of governance on environmental damages. The results found the importance of governance. Liu et al.(2020), for five countries that have high $\mathrm{CO}_{2}$ emission countries, explored the relationship btween governance, $\mathrm{CO} 2$ releases, and real GDP in the context of the EKC from 1996 to 2017 by the panel data methods. They showed that good governance is a way to test effective measures to protect and enhance environmentalquality.

If it is explored the literature of FDI in the context of governance, it is seen that some articles concentrate on this subject. Good governance systems are very important to increase the attractiveness of FDI (Lehnertet al., 2013; Gani, 2007). Peres et al.(2018), Nguyen(2015), Mengistu and Adhikary(2011), Gani(2007), Globerman and Shapiro(2002) determined a positive correlation among FDI and good governance. In less developed countries, it is accepted that FDI has detrimental impacts on the environment in the frame of exhaustible resources (Solow, 1974; Stiglitz, 1974; Bokpin et al., 2015). A few paper found that natural resources become the most important determinants of FDI flow to Africa. Bokpin et al., (2017) accented that FDI flows towards Africa are related with natural resource endowment and that they cause environmental degradation. Bokpin(2017) showed how FDI towards Africa contributes to the environmental degradation to situate Africa's FDI flows over the period of 19902013. The results determined that an rise in FDI inflows importantly rises environmental damages; and affirmed that there are need of strong governance and quality institutions to have non-negative effects on environmental sustainability of FDI. Omri and Hadj(2020), in 23 emerging countries over 1996- 
2014, tests how good governance complements FDI to diminish CO emissions. They found that increasing governance quality have negative effects on carbon emissions and that both institutional and political governance decrease the level of $\mathrm{CO}_{2}$ releases.

\section{Data and Definitions}

In this study, annual data covering the period of 1996-2018 for the Afghanistan, Angola, Bangladesh, Benin, Cameroon, Congo Dem., Congo, Chad, Central African Rep, Ethiopia, Ghana, Gambia,, Eritrea, Iraq, Kenya, Lesotho, Madagascar, Mali, Mozambique, Myanmar, Niger, Pakistan, Syria, Uganda, Zimbabweis employed. The variables used in the analysis are environmental pollution (co), FDI inflow (fdi), real GDP (y), and political governance $(p)$ and government effectiveness $(g)$ as a measure of governance. Economic growth is represented by realGDP (y) in constant 2005 USD. Real GDP (USD), FDI, and $\mathrm{CO}_{2}$ releases for the analyzed countries were obtained from the World Bank(WB). Two indicators as economic governance (government effectiveness) and political governance (political stability) were used. These variables were taken from the WGI (Worldwide Governance Indicators) database. It is expected a positive link between the reduction of $\mathrm{CO}_{2}$ emissions and these categories of governance indicators (Costantini and Monni, 2008). And it was used logarithmic transformation for the selected variables and they were converted as $\log \left(\right.$ variables $\left._{\mathrm{t}}\right)$

In these countries, in the context of political governance and economic effectiveness regional differences and the ethnic disputes deserve important attention. Some of these countries suffer from an ethnic heterogeneity problem which is an important factor that causes to political instability ${ }^{2}$. These countries have multi-ethnic structures to varying degrees. These problems strictly have the impacts on the economic and political development of the region.

In these countries, the level of environmental pollution is very high due to poor governance and other factors. Poor governance does not allow policy makers to adhere to strict environmental policies, and this is not enough to control corruption. Therefore, mismanagement creates more environmental pollution by resulting in higher $\mathrm{CO} 2$ emissions.

In Table 1, Global Environmental Index (EPI:2020) shows how far to establish the environmental policy goals of these countries.

161 Table 1: Scores of the countries

\begin{tabular}{|l|l|l|l|l|l|}
\hline Countries & EPI (2020)* & $\begin{array}{l}\text { 10-Year } \\
\text { Change }\end{array}$ & Countries & EPI(2020) & $\begin{array}{l}\text { 10-Year } \\
\text { Change }\end{array}$ \\
\hline Myanmar & $25.1(179)$ & -1.2 & Eritrea & $30.4(156)$ & -3.7 \\
\hline Afghanistan & $25.5(178)$ & 5 & Congo & $30.8(152)$ & -1.5 \\
\hline
\end{tabular}

\footnotetext{
${ }^{2}$ Political instability covers the increase in the effect of wars, civil wars, terror attacks, religious opposition, minorities, etc. Alesina et al. (1992), Tabellini and Alesina (1990), Alesina andTabellini (1989, 1990), Ozler andTabellini (1991), Cukierman et al. (1992), Gil-Alana and Barros (2010) discussed the economic inefficiencies of unstable political environment. But these papers did not analyze the environmental impacts. Political instability is generally experienced in developing countries in the World. According to GTI (2017), the number ofpolitical conflicts increased (almost doubled) in 2016. In 2006, SubSaharan Africa and Asia tracked by SubSaharan Africa had the highest growth in the number of conflicts. Since 2000, these countries have experienced many conflicts, wars, terror attacks, etc., which are accepted as sources of political instability. For example, Iraq- United States-led coalition War (2003- 2011), the conflict in Central AfricanRepublic BushWar (2004-07), the Niger Delta(2004-present), the Central AfricanRepublic conflict (2012-present), the ArabSpring (2010-12), Syrian civil war(2011-present) are a few of them. According to GTI (2018), Afghanistan experienced the highest amount of terrorism-connected deaths in 2017. In the same year, Iraq had the second-highest amount of deaths from terrorist attacks and the highest rate of rise in terrorism((IEP 2018); Bildirici and Gökmenoğlu:2020). Terrorist attacks, wars etc., increase environmental pollution as well as reducing the level of economic growth by damaging public and private capitals (Collier, et al. 2003); Bildirici and Gökmenoğlu(2020).
} 


\begin{tabular}{|l|l|l|l|l|l|}
\hline Cote d'Ivoire & $25.8(176)$ & -8.5 & Niger & $30.8(152)$ & -8.1 \\
\hline Guinea & $26.4(175)$ & -4.2 & Pakistan & $33.1(142)$ & 6.1 \\
\hline Madagascar & $26.5(174)$ & -6.6 & Cameroon & $33.6(139)$ & 1.5 \\
\hline Chad & $26.7(172)$ & -0.9 & Mozambique & $33.9(136)$ & 5.3 \\
\hline Ghana & $27.6(168)$ & -4.4 & Ethiopia & $34.4(134)$ & 0.2 \\
\hline Gambia & $27.9(166)$ & 3.6 & Kenya & $34.7(132)$ & - \\
\hline Lesotho & $28(165)$ & -1 & Uganda & $35.6(127)$ & 1.8 \\
\hline Bangladesh & $29(162)$ & -0.1 & Dem. Rep. Congo & $36.4(125)$ & -0.4 \\
\hline Mali & $29.4(160)$ & -3.3 & Central African Rep & $36.9(124)$ & -3.9 \\
\hline Angola & $29.7(158)$ & 5.3 & Zimbabwe & $37(123)$ & -7.3 \\
\hline Benin & $30(157)$ & 2.7 & Iraq & $39.5(106)$ & 0.2 \\
\hline
\end{tabular}

*EPI (2020) ranks 180 countries on 22 performance indicators. The numbers in parenthesis show rank within 180 countries for EPI (2020). EPI(2020) did not determine value for Syria

According to EPI (2020), the countries in the African continent have low scores in terms of environmental quality. Low scores show the need for domestic sustainability struggles.

Myanmar, Afghanistan, Cote d'Ivoire, Guinea and Madagascar are near the bottom of the rankings. These countries have more serious environmental damages.

\section{Econometric Methodology}

The methodology was presented in two stages. Firstly, Quantile panel regression test was presented. Secondly, panel causality tests were presented. And lastly, two different causality tests were supplied.

\subsection{Panel quantile Method}

The panelquantile regression that was suggested by Koenker and Basset(1978 )has some advantages over the OLS regression. Firstly, it can be obtained more robust the result from panel quantile regression(PQR)(Bera et al.:2016). And it is unneeded to shape distributional assumptions by employing PQR(Sherwood and Wang:2016). Furthermore, this technique can seizure the characteristics of the full conditional distribution of the selected variables (Yu and Jones:1998; Chen et al.(2018). Koenker \& Bassett (1982) proposed that Quantile regression is useful in examining asymmetric features of variable distributions (Chen and Lei: (2018)).

The conditional quantile of $y_{i}$ given as follows

$Q_{\text {coi }}\left(t \mid x_{i}\right)=x_{i}^{T} b_{t}$

$\mathrm{PQR}$ is robust to heavy distributions and outliers. In this paper, the fixed effect PQR method was used:

$Q_{y i}\left(t_{k} \mid a_{i}, x_{i t}\right)=a_{i}+x_{i t}^{T} b\left(t_{k}\right), \quad i=1, \ldots ., N ; t=1, \ldots, T$

$\mathrm{N}$ is the number of observations, and $\mathrm{t}$ is the index of time. The parameter estimate is calculated as follows

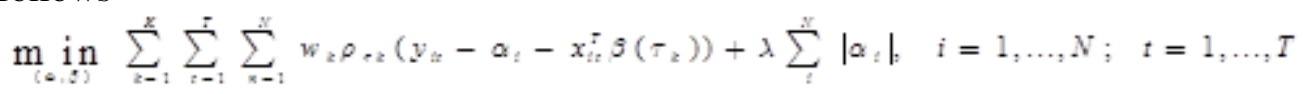

To estimate the impacts of FDI(fdi), economic growth (y), political governance(p) and economic governance $(\mathrm{g})$ on $\mathrm{CO} 2$ emissions, it was used equally weighted quantiles $w \mathrm{k}=1 / \mathrm{K}$ as Ang (2007) and 
Chen and Lei: (2018)) and set $l=1$ as Chen and Lei (2018). The conditional quantiles function is

given as follows

$Q_{c o i}\left(\tau \mid \alpha_{i t}, \xi_{t}, x_{i t}\right)=\alpha_{i}+\xi_{t}+\beta_{1 \tau} l g_{i t}+\beta_{2 \tau} l c_{i t}+\beta_{3 \tau} l y_{i t}+\beta_{4 l} l f d i_{i t}+\beta_{5 \tau} l p_{i t}$

196

197

198

199

200

201

202

203

204

205

206

207

208

209

210

211

212

213

214

215

216

co $p$ fdi $g$ y $c$

\section{Empirical Results}

In this paper, the empirical results were obtained in four steps:

1- The descriptive statistics and panel unit root tests were given.

2- Westerlund (2007) test determine cointegration result.

3- Panel Quantile regression, and DOLS and FMOLS tests suggested by Pedroni determined the longrun coefficients. DOLS and FMOLS tests were preferred to compare the results determined by quantile methods.

4- The direction of causal relation by traditional and Dumitrescu-Hurlin causality tests were determined.

\section{Descriptive Statistics}

In Table 2, the results showed that while 'co' variable is positively skewed, "g", "fdi”, "p" , and 'y' variables are negatively skewed.

Table 2. Statistics

\begin{tabular}{|l|c|c|c|c|c|}
\hline & co & $\mathrm{g}$ & $\mathrm{fdi}$ & $\mathrm{p}$ & $\mathrm{y}$ \\
\hline Kurtosis & 1.26 & 1.94 & 3.305 & 2.65 & 2.27 \\
\hline Jarque-Bera & 3.06 & 2.03 & 2.789 & 3.01 & 3.007 \\
\hline Skewness & 0.144 & -0.78 & -0.083 & -0.12 & -0.27 \\
\hline
\end{tabular}

The Unit Root Tests

Table 3 shows the findings determined by LLC, and IPS tests. The variables were found as an I(1).

Table 3. LLC and IPS Results

\begin{tabular}{|l|l|l|l|l|l|l|}
\hline & \multicolumn{1}{|c|}{ LLChu } & \multicolumn{1}{c|}{ IPS } & & \multicolumn{1}{c|}{ LLChu } & \multicolumn{1}{c|}{ IPS } & Decision \\
\hline$y$ & -1.87 & -2.18 & $d y$ & -12.62 & -15.83 & $\mathrm{I}(1)$ \\
\hline$p$ & -1.65 & 0.805 & $d p$ & -6.96 & -9.26 & $\mathrm{I}(1)$ \\
\hline$f d i$ & -1.23 & 1.32 & $d f d i$ & -7.14 & -8.032 & $\mathrm{I}(1)$ \\
\hline$c o$ & -1.63 & -2.19 & $d c o$ & -11.72 & -13.46 & $\mathrm{I}(1)$ \\
\hline$g$ & -1.86 & -1.47 & $d g$ & -7.88 & -10.018 & $\mathrm{I}(1)$ \\
\hline
\end{tabular}

After unit root tests, it was applied Westerlund (2007) test.

Table 4. The Cointegration Result

\begin{tabular}{|l|l|l|l|l|l|l|l|}
\hline$G_{t}$ & -3.117 & $G_{a}$ & -12.641 & $P_{t}$ & -13.921 & $P_{\alpha}$ & -11.729 \\
\hline
\end{tabular}

For the selected variables, in small sample size, $\mathrm{T}=25$, the results can exhibit the sensitivity to the selection of parameters as the kernel width and lag-lead lengths. Based on Persyn\&Westerlund (2008), cross-sectional dependencies were taken into account. When a shorter kernel window is used, the $\mathrm{H}_{0}$ of no cointegration was rejected by Westerlund test.

\section{Long-run Coefficients}


Pedroni DOLS and FMOLS results estimated the long-run relation. The coefficients of governance, and FDI are statistically significant in all models and they have effects on environmental pollution.

In Table 5, according to our results, all variables have statistically significant impacts on environmental pollution. The estimations of the FMOLS model disclose that a $1 \%$ increase in political governance and government governance increases environmental pollution by $0.44 \%$ and 0.367 respectively, and a $1 \%$ rise in FDI increases environmental pollution by $0.016 \%$.

Table 5. Quantile, and FMOLS and DOLS Results

\begin{tabular}{|c|c|c|c|c|c|c|c|}
\hline \multicolumn{8}{|c|}{ Dependent Variable: co } \\
\hline & \multicolumn{2}{|c|}{$\begin{array}{c}\text { Pedroni DOLS and } \\
\text { FMOLS }\end{array}$} & \multicolumn{5}{|c|}{ Quantile } \\
\hline & FMOLS & $P D O L S$ & 0.1 & 0.25 & 0.5 & 0.75 & 0.90 \\
\hline ly & $\begin{array}{r}0.09 \\
(2.93)\end{array}$ & $\begin{array}{l}0.13 \\
(2.4)\end{array}$ & $\begin{array}{r}0.14 \\
(13.4)\end{array}$ & $\begin{array}{l}0.063 \\
(2.61)\end{array}$ & $\begin{array}{l}0.05 \\
(2.75)\end{array}$ & $\begin{array}{l}0.114 \\
(7.10)\end{array}$ & $\begin{array}{l}0.207 \\
(3.63)\end{array}$ \\
\hline$l p$ & $\begin{array}{r}0.44 \\
(1.88)\end{array}$ & $\begin{array}{r}0.404 \\
(2.09) \\
\end{array}$ & $\begin{array}{l}0.136 \\
(1.85)\end{array}$ & 0.13 & $\begin{array}{l}0.143 \\
(2.29)\end{array}$ & $\begin{array}{l}0.328 \\
(1.82)\end{array}$ & $\begin{array}{l}0.822 \\
(4.62)\end{array}$ \\
\hline $\lg$ & $\begin{array}{l}0.367 \\
(2.83) \\
\end{array}$ & $\begin{array}{l}0.561 \\
(1.99)\end{array}$ & $\begin{array}{r}0.169 \\
(1.91)\end{array}$ & $\begin{array}{l}-0.011 \\
(1.75) \\
\end{array}$ & $\begin{array}{l}0.061 \\
(1.83)\end{array}$ & $\begin{array}{c}0.23 \\
(2.71)\end{array}$ & $\begin{array}{l}0.738 \\
(3.85)\end{array}$ \\
\hline lfdi & $\begin{array}{l}0.016 \\
(1.94)\end{array}$ & $\begin{array}{c}0.09 \\
(1.93)\end{array}$ & $\begin{array}{r}0.012 \\
(1.758)\end{array}$ & $\begin{array}{l}0.011 \\
(2.02)\end{array}$ & $\begin{array}{c}0.05 \\
(2.55)\end{array}$ & $\begin{array}{l}0.328 \\
(4.25)\end{array}$ & $\begin{array}{l}0.029 \\
(2.94)\end{array}$ \\
\hline
\end{tabular}

Accordingly, the determined results by the panel quantile regression underlined several significant points. The important effects of FDI and governance on $\mathrm{CO}_{2}$ emissions were seen. Furthermore, when compared with other variables, the political and government governance have the greatest positive effect on $\mathrm{CO} 2$ emissions across quantiles. The influential intensity of political governance on $\mathrm{CO}_{2}$ emissions changes from 0.13 to 0.822 . According to results, good governance system supports environmental regulations and decreases $\mathrm{CO}_{2}$ releases.

FDI cause increasing carbon releases, ranging from 0.011 to 0.328 . FDI increase carbon emissions in these countries due to the old-fashioned the technologies and due to insufficient environmental laws and regulations.

\section{Causality Results}

As the cointegration among the variables is determined, it is expected that through a feedback mechanism, a change in a variable has an influence on the other variables.

Table 6. Causality Results

\begin{tabular}{|c|c|c|c|c|}
\hline $\begin{array}{l}\Delta_{\mathrm{fdi}} \rightarrow \Delta_{\mathrm{co}} \\
\Delta_{\mathrm{co} \rightarrow} \Delta_{\mathrm{fdi}}\end{array}$ & $\begin{array}{l}\Delta_{\mathrm{y} \rightarrow} \Delta_{\mathrm{co}} \\
\Delta_{\mathrm{co} \rightarrow} \Delta_{\mathrm{y}}\end{array}$ & $\begin{array}{l}\Delta_{\mathrm{g}} \rightarrow \Delta_{\text {co }} \\
\Delta_{\mathrm{co}} \rightarrow \Delta_{\mathrm{g}}\end{array}$ & $\begin{array}{l}\Delta_{\mathrm{p} \rightarrow \Delta_{\mathrm{co}}} \\
\Delta_{\mathrm{co} \rightarrow \Delta_{\mathrm{p}}}\end{array}$ & $\begin{array}{l}\Delta_{\mathrm{fdi} \rightarrow} \rightarrow \Delta_{\mathrm{y}} \\
\Delta_{\mathrm{y} \rightarrow} \Delta_{\mathrm{fdi}}\end{array}$ \\
\hline $\begin{array}{l}3.48 \\
1.61\end{array}$ & $\begin{array}{l}4.34 \\
0.954\end{array}$ & $\begin{array}{l}3.56 \\
0.84\end{array}$ & $\begin{array}{l}4.83 \\
0.84\end{array}$ & $\begin{array}{l}4.83 \\
1.76\end{array}$ \\
\hline \multicolumn{5}{|c|}{ Causality Direction } \\
\hline $\mathrm{fdi} \rightarrow \mathrm{co}$ & $\mathrm{y} \rightarrow c o$ & $\mathrm{~g} \rightarrow \mathrm{co}$ & $\mathrm{p} \rightarrow \mathrm{co}$ & $y \rightarrow f d i$ \\
\hline $\begin{array}{l}\Delta_{\mathrm{fdi} \rightarrow} \rightarrow \Delta_{\mathrm{g}} \\
\Delta_{\mathrm{g} \rightarrow \Delta_{\mathrm{fdi}}}\end{array}$ & $\begin{array}{l}\Delta_{\mathrm{fdi} \rightarrow} \rightarrow \Delta_{\mathrm{p}} \\
\Delta_{\mathrm{p} \rightarrow \Delta_{\mathrm{fdi}}}\end{array}$ & $\begin{array}{l}\Delta_{\mathrm{g}} \rightarrow \Delta_{\mathrm{y}} \\
\Delta_{\mathrm{y}} \rightarrow \Delta_{\mathrm{g}}\end{array}$ & $\begin{array}{l}\Delta_{\mathrm{p}} \rightarrow \Delta_{\mathrm{y}} \\
\Delta_{\mathrm{y} \rightarrow \Delta_{\mathrm{p}}}\end{array}$ & $\begin{array}{l}\Delta_{\mathrm{p}} \rightarrow \Delta_{\mathrm{g}} \\
\Delta_{\mathrm{g} \rightarrow \Delta_{\mathrm{p}}}\end{array}$ \\
\hline $\begin{array}{l}4.55 \\
3.86\end{array}$ & $\begin{array}{l}5.56 \\
4.87 \\
\end{array}$ & $\begin{array}{l}7.93 \\
10.497\end{array}$ & $\begin{array}{l}3.93 \\
5.99\end{array}$ & $\begin{array}{l}3.27 \\
4.99\end{array}$ \\
\hline
\end{tabular}


251

252

253

254

255

256

257

258

259

260

261

262

263

264

265

266

267

268

269

270

271

272

273

274

275

276

277

278

\begin{tabular}{|c|c|c|c|c|}
\hline \multicolumn{5}{|c|}{ Causality Direction } \\
\hline $\mathrm{fdi} \leftrightarrow g$ & $\mathrm{p} \leftrightarrow \mathrm{fdi}$ & $\mathrm{y} \leftrightarrow g$ & $\mathrm{y} \leftrightarrow p$ & $\mathrm{~g} \leftrightarrow p$ \\
\hline
\end{tabular}

Table 7. Dumitrescu-Hurlin Test*

\begin{tabular}{|c|c|c|c|c|}
\hline $\begin{array}{l}\Delta_{\mathrm{fdi}} \rightarrow \Delta_{\mathrm{co}} \\
\Delta \mathrm{co} \rightarrow \Delta_{\mathrm{fdi}}\end{array}$ & $\begin{array}{l}\Delta_{\mathrm{y} \rightarrow} \Delta_{\mathrm{co}} \\
\Delta_{\mathrm{co} \rightarrow} \Delta_{\mathrm{y}}\end{array}$ & $\begin{array}{l}\Delta_{\mathrm{g} \rightarrow \Delta_{\text {co }}} \\
\Delta_{\mathrm{co}} \rightarrow \Delta_{\mathrm{g}}\end{array}$ & $\begin{array}{l}\Delta_{\mathrm{p} \rightarrow \Delta_{\mathrm{co}}} \\
\Delta_{\mathrm{co} \rightarrow \Delta_{\mathrm{p}}}\end{array}$ & $\begin{array}{l}\Delta_{\mathrm{fdi} \rightarrow} \Delta_{\mathrm{y}} \\
\Delta_{\mathrm{y} \rightarrow \Delta_{\mathrm{fdi}}}\end{array}$ \\
\hline \multicolumn{5}{|c|}{$\mathrm{W}_{\mathrm{N}, \mathrm{T}}^{\mathrm{hnc}}$} \\
\hline 3.99 & 4.54 & 3.68 & 6.093 & 4.944 \\
\hline 1.77 & 0.81 & 1.75 & 1.135 & 0.964 \\
\hline \multicolumn{5}{|c|}{ Causality Direction } \\
\hline $\mathrm{fdi} \rightarrow \mathrm{co}$ & $\mathrm{y} \rightarrow c o$ & $\mathrm{~g} \rightarrow \mathrm{co}$ & $\mathrm{p} \rightarrow \mathrm{co}$ & $y \rightarrow f d i$ \\
\hline$\Delta_{\mathrm{fdi} \rightarrow} \rightarrow \Delta_{\mathrm{g}}$ & $\Delta_{\mathrm{fdi} \rightarrow} \rightarrow \Delta_{\mathrm{p}}$ & $\Delta_{\mathrm{g} \rightarrow \Delta_{\mathrm{y}}}$ & $\Delta_{\mathrm{p} \rightarrow} \Delta_{\mathrm{y}}$ & $\Delta_{\mathrm{p} \rightarrow} \Delta_{\mathrm{g}}$ \\
\hline$\Delta_{\mathrm{g} \rightarrow} \Delta_{\mathrm{fdi}}$ & $\Delta_{\mathrm{p}} \rightarrow \Delta_{\mathrm{fdi}}$ & $\Delta_{\mathrm{y}} \rightarrow \Delta_{\mathrm{g}}$ & $\Delta_{\mathrm{y}} \rightarrow \Delta_{\mathrm{p}}$ & $\Delta_{\mathrm{g} \rightarrow \Delta_{\mathrm{p}}}$ \\
\hline \multicolumn{5}{|c|}{$\mathrm{W}^{\mathrm{hnc}} \mathrm{N}, \mathrm{T}$} \\
\hline 5.132 & 5.9356 & 5.65 & 5.36 & 5.35 \\
\hline 6.129 & 0.0851 & 5.32 & 6.61 & 6.47 \\
\hline \multicolumn{5}{|c|}{ Causality Direction } \\
\hline $\mathrm{fdi} \leftrightarrow g$ & $\mathrm{p} \leftrightarrow$ fdi & $\mathrm{y} \leftrightarrow g$ & $\mathrm{y} \leftrightarrow p$ & $\mathrm{~g} \leftrightarrow p$ \\
\hline
\end{tabular}

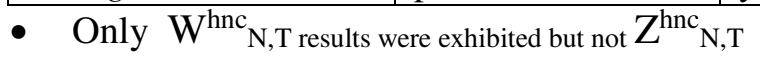

The results can be given as follows:

1- It was found that there is uni-directional causality running from economic governance to $\mathrm{CO}_{2}$ release. More clearly, bad economic governance is a Granger cause of environmental pollution.

2- It was found that there is uni-directional causal link running from political governance to environmental pollution.

3- The uni-directional causality from FDI to $\mathrm{CO}_{2}$ releases corrected the findings of the PHH. Production technology and insufficient environmental awareness are very important factors for increasing environmental pollution.

4- As approved by many papers, it was determined that there is uni-directional causality from $\mathrm{Y}$ to $\mathrm{CO}_{2}$ releases.

5- It was found the evidence of two-way causality between political governance and Y, between political governance and economic governance, between political governance and FDI, and between economic governance and FDI.

According to both traditional and Dumitrescu-Hurlin causality tests, there is uni-directional causal nexus from economic growth, political and economic governance, and FDI inflow to $\mathrm{CO}_{2}$ emission.

\section{Discussion}

Quantile regression results showed that economic and political governance have significant explanatory power on FDI inflow, $\mathrm{CO}_{2}$ releases, and real GDP. The coefficients of economic and politic 
governance, FDI and economic growth, are a positive signs in various quantiles (Table 6). The coefficients of government and politic governance in all the estimated models are positive and determine that bad government governance and political governance lead to increasing $\mathrm{CO} 2$ emissions.

In these countries, since the evidence of uni-directional causality from bad economic governance to $\mathrm{CO}_{2}$ release and the evidence of uni-directional causality from political governance to environmental pollution were determined, both the organizations and individuals are prevented from dealing with environmental quality due to impacts of bad governance.

And FDI cause increasing carbon emissions in changing ranges from 0.011 to 0.328 percent. Accordingly causality results, there is the evidence of uni-directional causality from FDI to $\mathrm{CO}_{2}$ releases. In these countries, the FDI inflows provide the important contribution to economic growth, but it leads to an increase in environmental pollution. Rising pollution caused by FDI is not controllable upto some extent, because these countries have the problems of economic development, and in these countries, FDI is vital for economic development. But FDI increase carbon emissions in these countries due to the oldfashioned the technologies and due to insufficient environmental laws and regulations. Because bad governance is to prevent government policies for addressing environmental issues caused by FDI. In this countries, there is bi-directional causality between FDI and governance. In these countries FDI is sensitive bad governance, bad governance attracts FDI and FDI causes bad governance

On the other hand, the governments must apply incentive policies to attract high-tech firms to further invest in their countries, and on the other hand, to limit the entry of polluting industries into the country, they must have strict environmental regulations. The government policies should look after the efficient and environmentally-friendly source consumption of FDIs. And lastly, governments must embrace green policies to decrease pollution. As a results, good political and economic governance can decrease environmental pollution. These countries have need to good governance because good governance covers the protection of the environment and sustainable natural sources.

\section{Conclusions}

This paper tested the relation between governance and environmental pollution with additional two variables such as real GDP, and FDI inflow in Afghanistan, Angola, Bangladesh, Benin, Cameroon, Congo Dem., Congo, Chad, Central African Rep, Ethiopia, Ghana, Gambia,, Eritrea, Iraq, Kenya, Lesotho, Madagascar, Mali, Mozambique, Myanmar, Niger, Pakistan, Syria, Uganda, Zimbabwe for the period of 1996-2018 by utilizing panel tests. Panel cointegration test determined the presence of cointegration among the selected variables. The panel Quantile regression, and FMOLS and DOLS methods found the effects of government and political governance, and FDI on environmental pollution. The coefficients of economic and politic governance in all the estimated models are positive and determine that an increase in good economic governance and bad political governance will lead to increasing $\mathrm{CO} 2$ emissions. Both traditional and Dumitrescu-Hurlin causality approaches were employed to determine the evidence of the causality between the analyzed variables. The results determined unidirectional causality from governance, and FDI inflow to environmental pollution.

Despite unsustainable development, the policymakers do not have the opportunity to choose the variables which have adverse effects on the environment. Bad governance is to prevent government policies for addressing environmental issues. The political stability helps to control $\mathrm{CO} 2$ emissions and, to recover environmental quality. Decreasing $\mathrm{CO} 2$ emissions with better political institution can be provided, because stability is one of the most significant requirements of environmental quality.

As a result, unless the bad governance is solved, the policies executed on environmental sustainability will not give the expected results. 
This paper were not previously published in any journal. It is currently not under consideration by another journal. The author accepted and decided to submit the paper to ESPR journal

CompetingInterest: In accordance with journal's policy and my ethical obligation as a researcher, I have not any conflict of interest.

\section{Funding: This paper has not any funding source}

DataAvilability: All data are received from official source

Author Contributions: All paper was prepared by the author

\section{REFERENCE}

Abid M.,2016, Impact of economic, financial, and institutional factors on CO2emissions: evidence from sub-Saharan Africa economies. Util Policy 41:85-94

Bera; Galvao, A.K.; Montes-Rojas, A.F.; Park, G.V.; Sung, Y. 2016, Asymmetric Laplace Regression: Maximum Likelihood, Maximum Entropy and Quantile Regression. J. Econom. Methods 5, 79-101

Cheng C., Ren X., Wang Z., Shi Y., 2018, The Impacts of Non-Fossil Energy, Economic Growth, Energy Consumption, and Oil Price on Carbon Intensity: Evidence from a Panel Quantile Regression Analysis of EU 28, Sustainability, 10, 4067

Danish, Baloch MA, Wang B. 2019, Analyzing the role of governance in CO2 emissions mitigation: the BRICS experience. Struct Chang Econ Dyn 51:119-125

Foster J.B.,2010, Marx's Ecology and Its Historical Significance," in Michael R. Redclift and Graham Woodgate, eds., Inter.l Hand. of Environ.l Sociol., 2nd ed. Northampton, MA: Edward Elgar, 106-20

Foster J.B., 2009, The Ecological Revolution. New York: Monthly Review Press, 161-200.

Fredriksson, P. G., \& Svensson, J. 2003 . Political instability, corruption and policy formation: The case of environmental policy. Journal of Public Economics, 87 7/8 , 1383-1405.

Freytag, A., Krueger, J., Meierrieks, D. Schneider, F. 2011 , The origins of terrorism: Crosscountry estimates on socio-economic determinants of terrorism. Europ. J. Pol. Econ., 27: 5-16.

Gil-Alana L. and Barros C., 2010, A Note on the Effectiveness of National Anti-Terrorist Policies: Evidence from ETA, Conflict Management and Peace Science, 27(1), 28-46

Goel RK, Herrala R, Mazhar U.2013, Institutional quality and environmental pollution: MENA countries versus the rest of the world. Econ Syst 37:508-521.

Gökmenoğlu, K. and Taspinar N., 2016, The relationship between $\mathrm{Co}_{2}$ emissions, energy consumption, economic growth and FDI: the case of Turkey, 28(5), 706-723 161.

Hadri, K. 2000. Testing for stationarity in heterogeneous panel data. Econometrics Journal 3: 148-

Hassan ST, Danish, Khan Sud et al (2020) Role of institutions in correcting environmental pollution: an empirical investigation. Sustain Cities Soc 53

Harrison D, 1992 Tourism \& the Less Developed Countries. Belhaven Press: London.

Hoffman, R., Lee C.G., Ramasamy B., Yeung M., 2005 , FDI and pollution: a Granger causality test using panel data, J. Int. Dev.,17 $3: 311-317$. 
Hosseini HM, Kaneko S (2013) Can environmental quality spread through institutions? Energy Policy 56:312-321

Im, K. S., Pesaran M.H. Shin Y., 2003 , Testing for unit roots in heterogeneous panels', J. Economet., 115: 53-74.

Im, K.S., Pesaran, M.H. and Shin, Y., 2003 , Testing for Unit Roots in Heterogeneous Panels. J. Econom., 115:53-74

Jaffe, A.B., Peterson S.R., Portney P.R., Stavins R., 1995 , Environmental regulation and the competitiveness of US manufacturing, J.Econ. Lit., 33 :132-163

Kaika D., Zervas E., 2013. The Environmental Kuznets Curve EKC theory-Part A: Concept, causes and the CO2 case, Ener. Pol., 62: 1392-1402

Kariuki, C. (2015). The determinants of foreign direct investment in the African Union. Journal of Economics, Business and Management, 3(3), 346

Kaufmann D. 2007. Corruption governance and security, Challenge for rich countries. World Bank on line. Available at http://www.worldbank. org/wbi/governance/pdf/Kaufmann_GCR_101904_B.pdf accessed 25 June 2008 .

Koenker, R.; Bassett, G. Regression Quantiles. Econometrica 1978, 46, 33-50.

Kuznet, S. 1955 . Economic growth and income inequality. The American economic review, XLV $1 ; 1-28$

Kuo, N. W., \& Chen, P. H. 2009 . Quantifying energy use, carbon dioxide emission, and other environmental loads from island tourism based on a life cycle assessment approach. Journal of Cleaner Production, 1715 , 1324-1330.

Leitao A (2016) Corruption and the environment. J Sociol 5:2-5.

Levin, A., C.F. Lin, Chu C.S., 2002 , Unit root tests in panel data: asymptotic and finite-sample properties. J. Economet.,108: 1-24

Lovelock, J. 2006 The Revenge of Gaia. New York: Basic Books.

Maji I.K., Habibullah MS and Saari MY. Financial development and sectoral $\mathrm{CO}_{2}$ emissions in Malaysia, Environ Sci Pollut Res, 2017;24 8 :7160-7176

Mark N., Sul D., 2003 , Cointegration vector estimation by panel DOLS and long-run money demand, Oxford Bullet. of Econ. and Statis., 655 :655-680

Moghadam HE, Lotfalipour MR., 2014 , Impact of financial development on the environmental quality in Iran. Chin Bus Rev.,13:537-551

Muzindutsi, P.F.; Manaliyo, J.C. 2016 , Effect of Political Risk Shocks on Tourism Revenue in South Africa: Time Series Analysis. Int. J. Bus. Manag. Stud., 8, 170-186.

Omisakin, A., Olusegun. 2009 , Economic growth and environmental quality in Nigeria: does environmental Kuznets curve hypothesis hold? Environ. Res. J., 3:14-18.

Onyeiwu, S., \& Shrestha, H. (2004). Determinants of foreign direct investment in Africa. Journal of Developing Societies, 20(1-2), 89-106.

Peng H., Tan X., Li Y, Hu L., 2016 , Economic growth, foreign direct investment and $\mathrm{CO}_{2}$ emissions in China: A Panel Granger Causality Analysis, Sustainability;8 1-13

Peres, M., Ameer, W., Xu, H., 2018. The impact of institutional quality on foreign direct investment inflows: evidence for developed and developing countries. Econ. Res.-Ekonomska Istraživanja 31, 626644

Persyn D. and Westerlund J., 2008 , Error-correction-based cointegration tests for panel data, The Stata Journal, $82 ; 232-241$. 
Purcel A. 2019 , Does Political Stability Hinder Pollution? Evidence From Developing States , Econ Res Guard 92 : 75-98

Radic 2018 , Terrorism as a Determinant of Attracting FDI in Tourism: Panel Analysis Sustainability, 10, 4553

Saenz-de-Miera, O., \& Rossell_o, J. 2014 . Modeling tourism impacts on air pollution: the case study of PM10 in Mallorca. Tourism Management, 40, 273-281

Sajjad, F., Noreen, U., \& Zaman, K. 2014 . Climate change and air pollution jointly creating nightmare for tourism industry. Environmental Science and Pollution Research, 2121 , 12403-12418.

Smarzynska BK, Wei SJ. , 2001 , Pollution havens and foreign direct investment: dirty secret or popular myth? NBER Working Paper 2001:8465.

Sherwood, B.; Wang, L. 2016, Partially linear additive quantile regression in ultra-high dimension. Ann. Stat., 44, 288-317.

Stiglitz, J.E., 1974. Growth with exhaustible natural resources: efficient and optimal growth paths. Rev. Econ. Stud. Symp., 123-137.

Tahvonen, O., 2000. Economic Sustainability and Scarcity of Natural Resources: A brief historical review. Resources for the Future. Available from: 〈www.rff.org $\rangle$.

Wang, D. T., \& Chen, W. Y. 2014. Foreign direct investment, institutional development, and environmental externalities: Evidence from China. Journal of Environmental Management, 135, 81-90.

Wang Z, Danish ZB, Wang B, 2018. The moderating role of corruption between economic growth and CO2 emissions: evidence from BRICS economies. Energy 148:506-513.

Welsch, H. 2004 . Corruption, growth, and the environment: A cross-country analysis. Environment and Development Economics, 9, 663-693.

Yu, K.; Jones, M.C., 1998, Local Linear Quantile Regression. Publ. Am. Stat. Assoc., 93, 228-237. 